\title{
Analisis Post To Subscribe Youtuber Pada 10 Youtuber Indonesia Dengan Jumblah Subscribe Terbanyak
}

\author{
Efrida Eko
}

elfridaeko97@gmail.com

\begin{abstract}
Youtube is one of the media that is a source of information for millennial consumers to assist them in forming interest and making purchasing decisions. Various kinds of video content with purposes ranging from entertainment to information education, made by independent parties both companies and individuals are available on Youtube, Beauty vlogger is one of the parties who make video content on YouTube, where the videos they produce are about all kinds of information about the world. beauty. Some beauty vloggers have a very large number of millennial-aged followers, which makes them an online opinion leader for millennial consumers.
\end{abstract}

\begin{abstract}
ABSTRAK
Youtube merupaan salah satu media yang menjadi sumber informasi bagi para konsumen millenials untuk membantu mereka dalam membentu minat sekaligus pengambilan keputusan pemeblian. Beragam macama video konten dengan tujuan mulai dari hiburan sampe edukasi informasi, dibuat oleh pihak indenpenden baik perusahan maupun individu telah tersedia di Youtube, Beauty vlogger adalah salah satu pihak yang membuat video konten di YouTube, dimana video yang mereka breisi tentang segala sesuatu informasi mengenai dunia kecantikan. Beberapa beauty vlogger memeiliki basis pengikut berusia millenials dengan jumblah yang sangat besar, yang menjadian mereka sebagi online opinion leader bagi para konsumen millenias.
\end{abstract}

Keyword : parasocial interaction, beauty vlogger, konsumen millenials dan purchse intention. 


\section{Latar Belakang}

Dengan perkembangan teknologi yang semakin teknologi yang semakin pesan semakin mudah pula seseorang bisa mengakses berbagai macam video, gambar, ebook, atau pun artikel. Akibatnya banyak yang menggunakan media internet sebagai tempat pelarian untuk mencari hal-hal baru, contohnya seperti di YouTube semua orang bisa mengakses berbagai macam video yang telah diunggah oleh orang banyak pemanfaatan YouTube ini dapat berdampak positif bagi penggunanya bila digunakan untuk mencari berbagai macam tutorial atau pun mengunggah video yang kita punya. Bila YouTube hanya digunakan untuk mencari video yang tidak etis, maka hal tersebut dapat berdampak negatif bagi penggunanya.

YouTube adalah sebuah situs web video sharing (berbagi video) populer dimana para pengguna dapat memuat, menonton, dan berbagai klip video secara gratis. Umumnya video- video di YouTube adalah klip musik, film, televisi, serta video buatan para penggunanyasendiri. Format yang digunakan video-video di YouTube adalah FLV yang dapat di putar di penjelajah web yang memilikiPlugin Flash Player. Menurut perusahaan penelitian Internet Hitwise, pada Mei 2006 YouTube memiliki pangsa pasar sebesar 43 persen. YouTube didirikan pada Februari 2005 oleh tiga orang bekas karyawan Pay Pal: Chad Hurley, Steve Chen, dan Jawed Karim. Media sosial Youtube digemari oleh masyarakat untuk berbagai macam sarana. Baik untuk sekedar melihat video atau pun mengunggah video kedalam YouTube. YouTube sendiri memiliki banyak manfaat, diantaranya adalah untuk mencari film, melihat musik, video terbaru, dan lain sebagainya. Tidak lepas dari itu Youtube juga memiliki kekurangan misalnya kurang penyaringan antara video yang mencerminkan citra negatif karena untuk pengambilan dan mengunggah dalam bentuk video tidak ada batasan khusus jadi masyarakat dapat secara bebas mengunggah video dari YouTube. Media sosial ini sangat menarik untuk dibahas karena banyak hal yang menjadi pro dan kontra pada situs ini. Tidak sedikit masyarakat yang telah mengakses situs ini, terlebih lagi para remaja kalangan Sekolah Menengah Atas sampai mahasiswa sering sekali mengakses situs ini. Banyak masyarakat yang beranggapan bahwa YouTube sebagai sarana penyaluran bakat, namun adapula dari situs ini sebagian masyarakat memanfaatkannya sebagai ajang kreativitas. Persepsi orang mengenai media sosial YouTube berbeda-beda karena fungsi yang paling utama dalam media ini adalah mengaplikasikan suatu objek agar dapat disaksikan oleh para pengguna media tersebut. Penelitian ini menggunakan metode eksploratif kuantitatif, dan akan menghitung menggunakan rasio-rasio yang ada pada youtube.

Penelitian ini hanya berfokusuntuk menghitung kredibilitas Video post to subscriber Ratio Youtube Pada 5 Artis Paling Kaya Di Indonesia. Tujuan dari penelitian ini adalah mengetahui kredibilitas performa dari akun youtube 5 artis paling kaya di Indonesia menggunakan Video post to subscriber Ratio. 


\section{TINJAUAN PUSTAKA YOUTUBE}

Youtube adalah sebuah situs web berbagi video yang dibuat oleh tiga mantan karyawan PayPal pada Februari 2005. Situs ini memungkinkan pengguna mengunggah, menonton, dan berbagi video. Perusahaan ini berkantor pusat di San Bruno, California, dan memakai teknologi Adobe Flash Video dan HTML5 untuk menampilkan berbagai macam konten video buatan pengguna, termasuk klip film, klip TV, dan video musik. Selain itu ada pula konten amatir seperti blog video, video orisinal pendek, dan video pendidikan. Dengan banyaknya pengguna youtube di Indonesia menimbulkan kegemaran baru, kegemaran tersebut dapat menciptakan penghasilan baru bagi para pengguna youtube tersebut. Youtube merupakan suatu wadah untuk menciptakan suatu popularitas baru dengan bertujuan untuk mendapatkan suatu keuntungan. Tidak sedikit para artis televisi berpindah haluan menjadi artis youtube dikarenakan youtube lebih diminati oleh masyarakat daripada televisi, hal ini sesuai dengan slogan dari youtube itu sendiri yaitu "youtube lebih dari sekedar TV". Keuntungan yang didapatkan di dalam youtube dapat berupa suatu popularitas atau bahkan penghasilan tambahan . dengan pengaksesan dan peraihan penghasilan yang mudah membuat youtube menjadi salah satu lahan pekerjaan. baru yang diciptakan secara tidak sengaja atau secara kebetulan, karena pada dasarnya para pelaku usaha di media sosial youtube hanya melakukan kegemarannya saja namun kegemaran itu dapat memunculkan penghasilan didalamnya. Youtuber merupakan sebutan bagi para pemilik akun youtube yang aktif mengunggah video di youtube tersebut. Youtuber dapat berbentuk orang pribadi atau individu, kelompok ataupun perusahaan besar yang menggunakan youtube sebagai media untuk memperkenalkan dirinya baik barang atau jasa yang diperjualbelikan. Tidak sedikit youtuber yang menyebut dirinya sebagai influencer marketing yang bekerja pada bidang memasarkan suatu barang atau jasa di media sosial khusunya youtube. Syarat menjadi seorang influencer marketing menurut IDN Times adalah minimal memiliki followers aktif sejumlah 3000 sudah dapat dikatakan sebagai seorang influencer marketing.18 Youtube memfasilitasi penggunanya untuk mengunggah video dan bisa diakses oleh pengguna lain di seluruh dunia secara gratis. Dikarenakan hal ini membuat popularitas youtube menjadi lebih meningkat karena menambah variasi di setiap tampilannya. Tidak ada pembatasan durasi yang diberikan oleh youtube membuat nilai tambah bagi youtube dibandingkan dengan media sosial lainnya seperti Instagram. Dapat diketahui bahwa durasi pengunggahan video didalam Instagram hanya sekitar 1 menit saja, hal ini diyakini tidak efektif dalam melakukan proses pemasaran

suatu produk ataupun jasa karena durasi yang begitu singkat, sehingga banyak masyarakat yang lebih memilih youtube sebagai media yang dipilih. Selain itu youtube juga merupakan sarana mencari informasi dengan lebih mudah karena metode video yang digunakan dan dapat lebih mudah dicerna oleh masyarakat luas.19 Tidak hanya informasi saja youtube juga dapat digunakan sebagai media hiburan 
dimana bisa mengakses musik dan lagu serta cuplikan film-film sehingga menimbulkan pemikiran dari masyarakat bahwa slogan cuplikan film-film sehingga menimbulkan pemikiran dari masyarakat bahwa slogan dari dari youtube yang menyatakan bahwa "lebih dari sekedar TV" memanglah pas adanya. Dikarenakan akses jaringan youtube bisa mencapai seluruh dunia. Tidak jauh berbeda dengan fungsi search engine, pecarian di youtube akan muncul daftar sejumlah video sesuai denga kata kunci yang telah dicantumkan didalam pencarian tersebut. Dari hasil pencarian akan muncul top rated, most viewed dan most recent di halaman utama youtube dan jumlah video yang berhubungan dengan kata kunci di dalam pencarian tersebut. 


\section{METODE PENELITIAN}

Keterangan :

Metode Penelitian merupakan teknik pengumpulan, pengolahan, dan analisis data. Isi metode mencakup sumber data, waktu pengambilan data, populasi dan sampel, penyajian data, dan Teknik analisis data. Metode ini menentukan ketajaman hasil analisis data di bagian hasil dan pembahasan penelitian. Penelitian ini menggunakan metode eksploratif kuantitatif untuk mengetahui kredibilitas dari performa akun youtuber 10 youtuber Indonesia dengan jumblah subscribe terbanyak Metode eksploratif merupakan penelitian yang memiliki tujuan untuk melakukan eksplorasi atau memperdalam pengetahuan ataupun ide-ide baru mengenai suatu hal yang baru, guna merumuskan permasalahan secara terperinci Tujuan dari penelitian ini yaitu mengetahui nilai kredibillitas dari performa akun youtuber 10 youtuber Indonesia dengan jumblah subscribe terbanyak Ada beberapa langkah yang harus dilakukan dalam penelitian ini, sehingga mampu menemukan peringkat pertama akun youtuber 10 youtuber Indonesia dengan jumblah subscribe terbanyak yang memiliki performa terbaik. Langkah-langkah yang dilakukan pada penelitian ini, diantaranya yaitu :

1. Melakukan Eksplorasi Pada Website Untuk Menentukan Objek yang Akan Dianalisa.

Eksplorasi ini dilakukan pada beberapa halaman website yang menyediakan informasi mengenai objek yang akan di teliti. Setelah ekslorasi selesai dilakukan, sehingga ditemukan nama-nama youtuber di Indonesia yang akan dijadikan objek analisa. Setelah melakukan eksplorasi pada halaman website, maka langkah selanjutnya yaitu mencari nama akun youtuber dari masing-masing youtuber. Pastikansemua memiliki akun pada aplikasi sosialmedia youtube

\section{Menghitung Nilai Rata-Rata Variable Dari 10 youtuber Indonesia dengan jumblah}

subscribe terbanyak Pada langkah ini, peneliti menghitung nilai variable video comments dan variable video views. Variabel merupakan sesuatu yang memiliki nilai bervariasi dimana nilai tersebut dapat dijadikan sebagai dasar untuk empat data yang berbeda seperti rasio, skala, ordinal, nominal dan internal Untuk menghitung nilai rata-rata dari variabel video comments dan variabel video views yaitu dengan cara mengambil minimal 10 postingan kemudian di hitung sehingga menemukan nilai rata-rata darimasingmasing variabel

Keterangan : 
Metode Penelitian merupakan teknik pengumpulan, pengolahan, dan analisis data. Isi metode mencakup sumber data, waktu pengambilan data, populasi dan sampel, penyajian data, dan teknik analisis data. Metode ini menentukan ketajaman hasil analisis data di bagian hasil dan pembahasan penelitian.

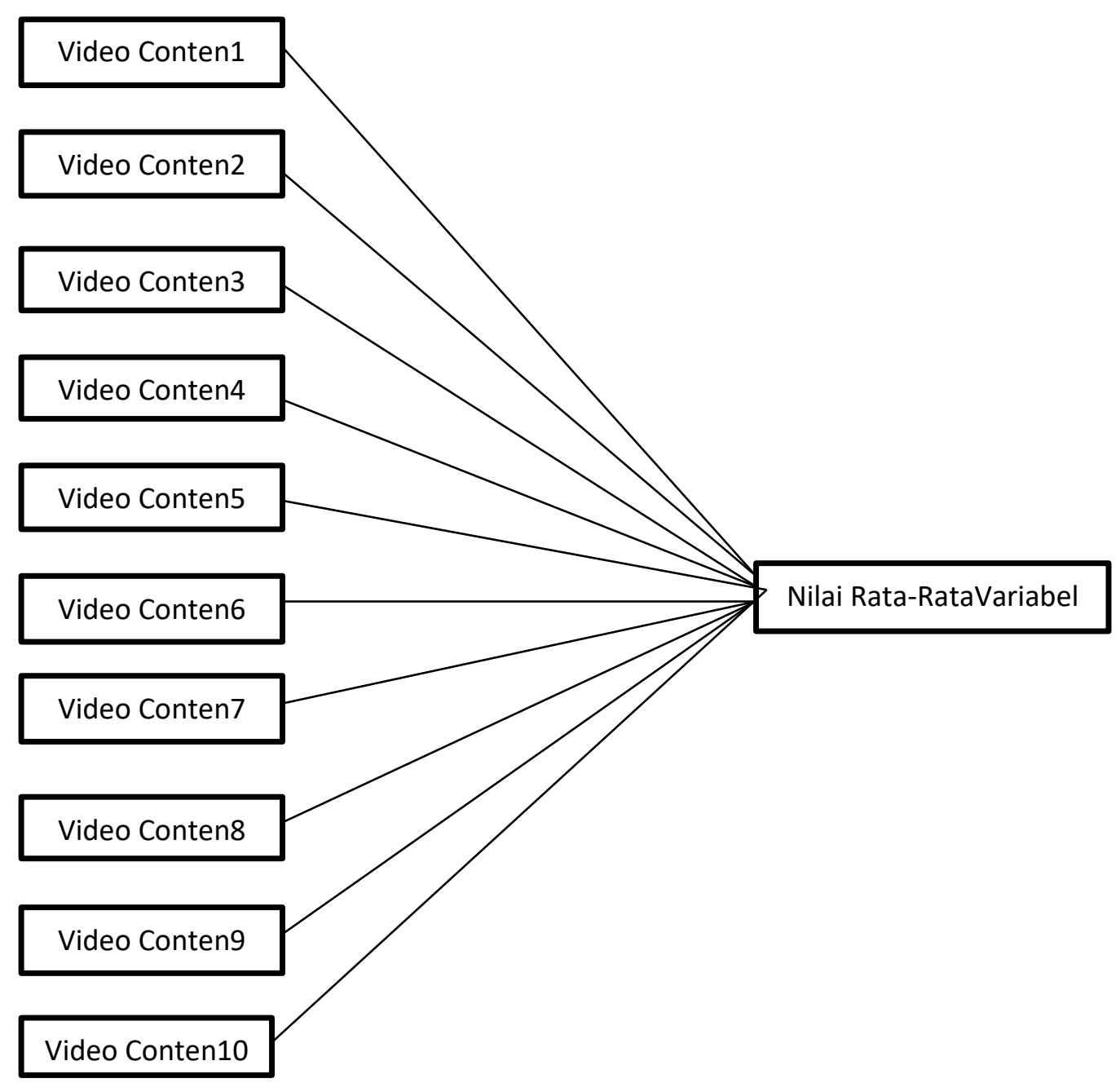

Gambar 1. Analisa Nilai Rata-Rata Variabel.

\section{Menghitung Nilai Kredibilitas Rasio}

Untuk menghitung nilai kredibilitas dari post to subscribe ratio, peneliti menggunakan cara membagi nilai variabel pertama dengan nilai variabel kedua. Jika video comments memiliki nilai 100 dan video views memiliki nilai 300, maka cara menghitungnya yaitu $100: 300=0,3$. Dengan begitu nilai dari video comments to video views ratio adalah0,3.

\section{Menentukan Peringkat Pada Akun youtuber}


Pada langkah terakhir yang dilakukan pada penelitian ini yaitu menentukan peringkat pada masing- masing rasio yang ada. Pada penentuan peringkat perlu melihat karakteristik dari rasio yang di teliti. Jika karakteristik rasio merupakan rendah, maka objek yang memiliki nilai terendah akan mendapatkan angka 5 dan objek yang memiliki nilai tertinggi akan mendapatkan angka 1. Namun jika rasio memiliki karakteritik tinggi maka objek yang mendapatkan nilai tinggi akan mendapatkan angka 5 dan objek yang mendapatkan nilai terendah akan mendapatkan angka 1. Setelah mendapatkan hasil kredibilitas ratio maka dapat disimpulkan objek yang mana mendapatkan peringkat 1sampai dengan peringkat 5 . 


\section{HASIL DAN PEMBAHASAN}

Akun Youtuber dari 10 youtuber indonesia dengan jumblah subscribe terbanyak

\section{Ata Hallilintar}
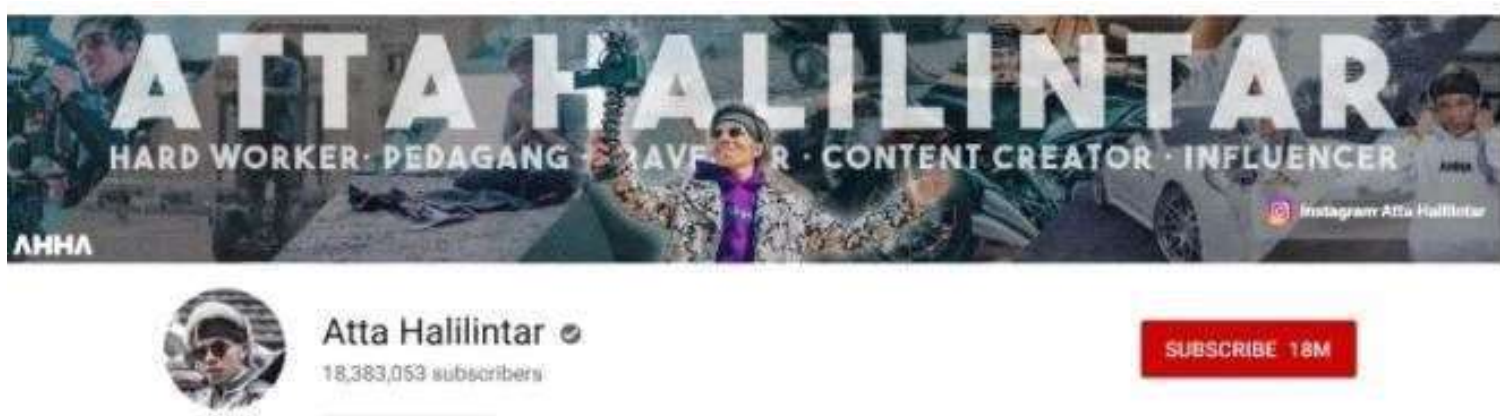

Atta Halilintar 0

$18,383,053$ sibionibers

\section{SUESCRiBe $18 \mathrm{M}$}

HOME

vioeos

PIAYLSTS

COMMUNITY

CHANNEIS

ABOUT

Gambar 1. Akun youtube Ata Hallilintar

Sumber: https://carisinyal.com/youtuber-dengan-subscriber-terbanyak/ (akses pada 22 -102021)

\section{Ricis Official}

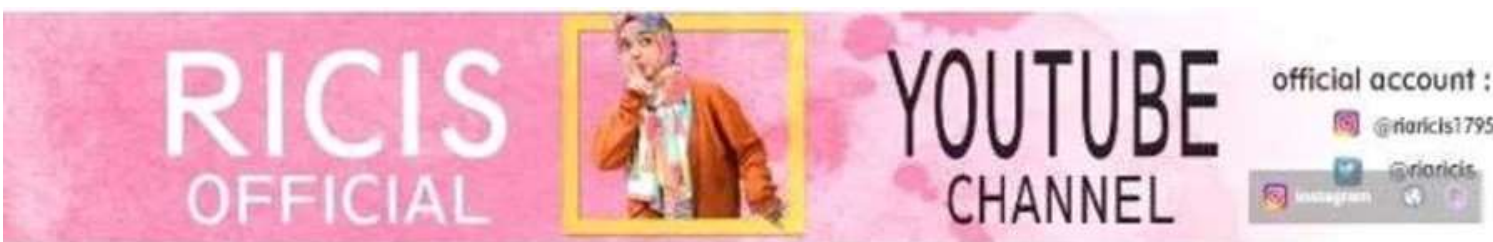

(2) Ricis Official o

16,244,177 subscribers

HOME

VIDEOS

PLAYLISTS

COMMUNITY

CHANNALS

\section{SUESCRIBE $16 \mathrm{M}$}

Gambar 2. Akun Youtube Ricis Official

Sumber:: https://carisinyal.com/youtuber-dengan-subscriber-terbanyak/ (akses pada 22 -102021)

\section{Gen Halilintar}




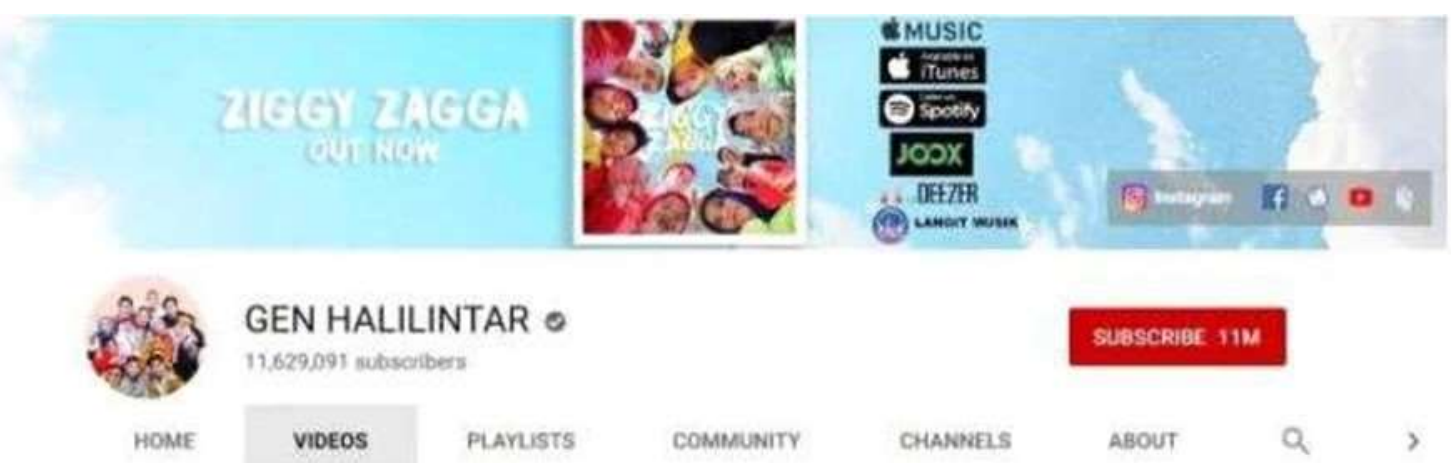

Gambar 3. Akun youtube Gen Halilintar

Sumber:: https://carisinyal.com/youtuber-dengan-subscriber-terbanyak/ (akses pada $22-10-2021)$

\section{Rans Entertainment}

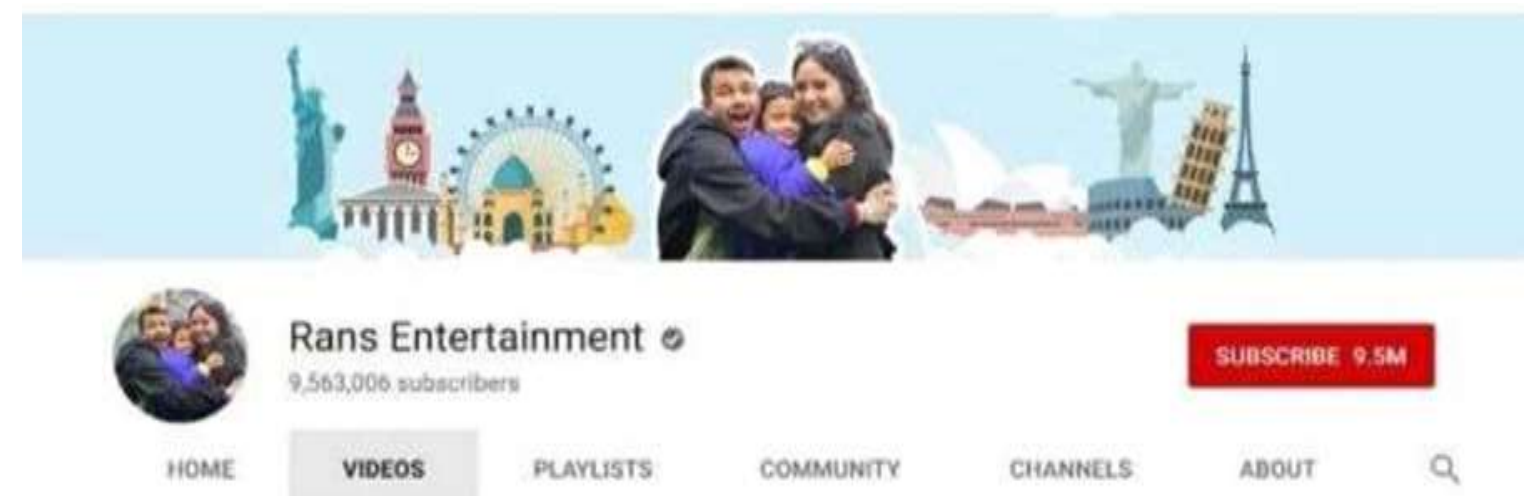

Gambar 4. Akun Youtube Rans Entertainment

Sumber:: https://carisinyal.com/youtuber-dengan-subscriber-terbanyak/ (akses pada 22 -102021)

\section{Raditya Dika}

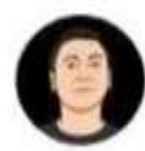

HOME
Raditya Dika o

$7,417,802$ subseribers
VIDEOS
SuBschibe $7.4 \mathrm{M}$

COMMUNITY

CHANNELS

ABOUT

Gambar 5. Akun Youtube Raditya Dika 
Sumber:: https://carisinyal.com/youtuber-dengan-subscriber-terbanyak/ (akses pada 22 -102021)

\section{Baim Paula}

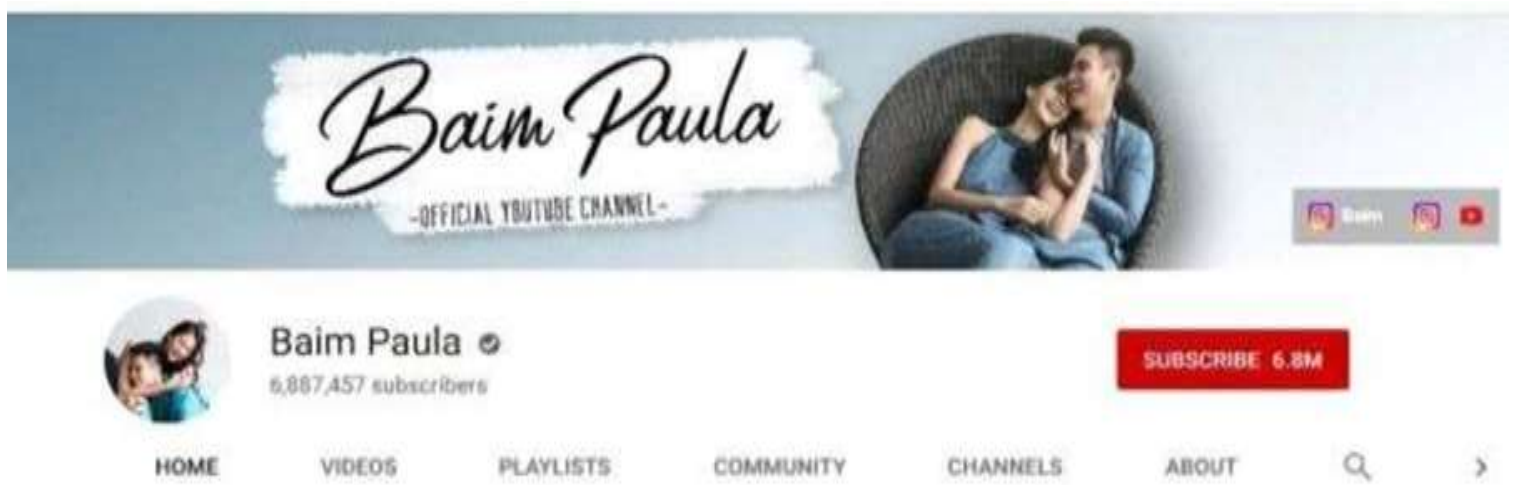

Gambar 6. Akun Youtube Baim Paula

Sumber:: https://carisinyal.com/youtuber-dengan-subscriber-terbanyak/ (akses pada 22 -102021)

\section{Jess No Limit}
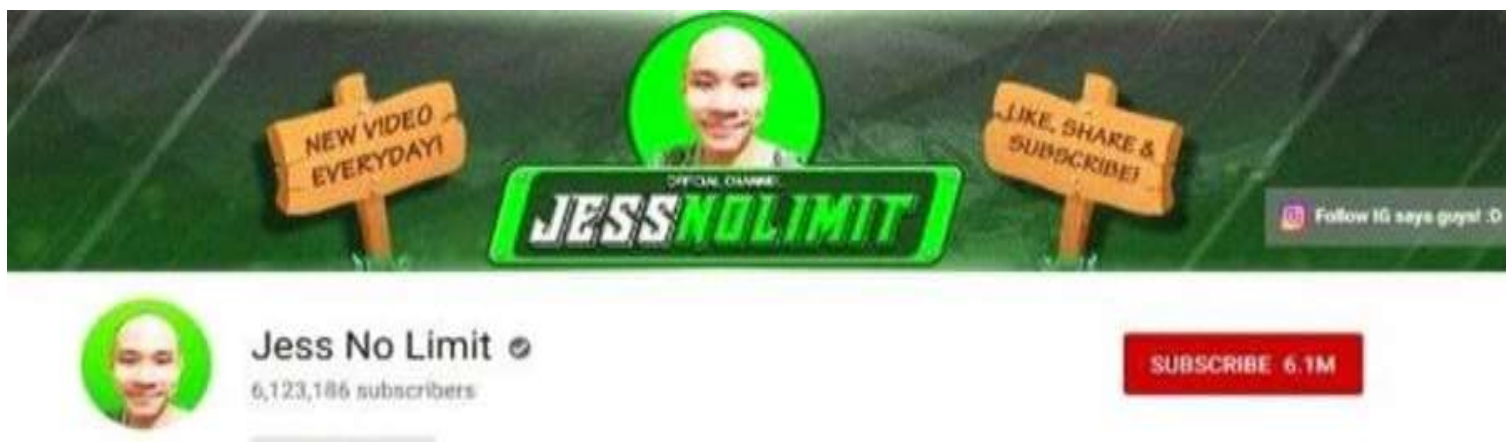

Jess No Limit 0

6,123,136 subscribers

HOME.

VIDEOS

PLAYLISTS

COMMUNITY

CHANNELS

\section{SUBSCRBEE $6.1 \mathrm{M}$}

ABouT

Gambar 7. Akun Youtube Jess No Limit

Sumber: https://carisinyal.com/youtuber-dengan-subscriber-terbanyak/ (akses pada 22 -102021)

\section{Deddy Corbuzier}




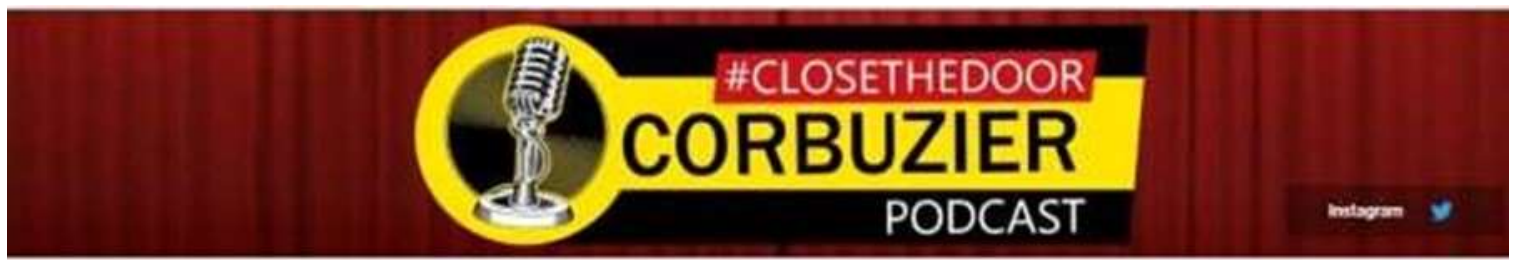

Deddy Corbuzier o

Sumber: https://www.youtube.com/results?search_query=deddy+corbuzier (akses pada 22 -10-2021)

\section{9. the shiny peanuts}
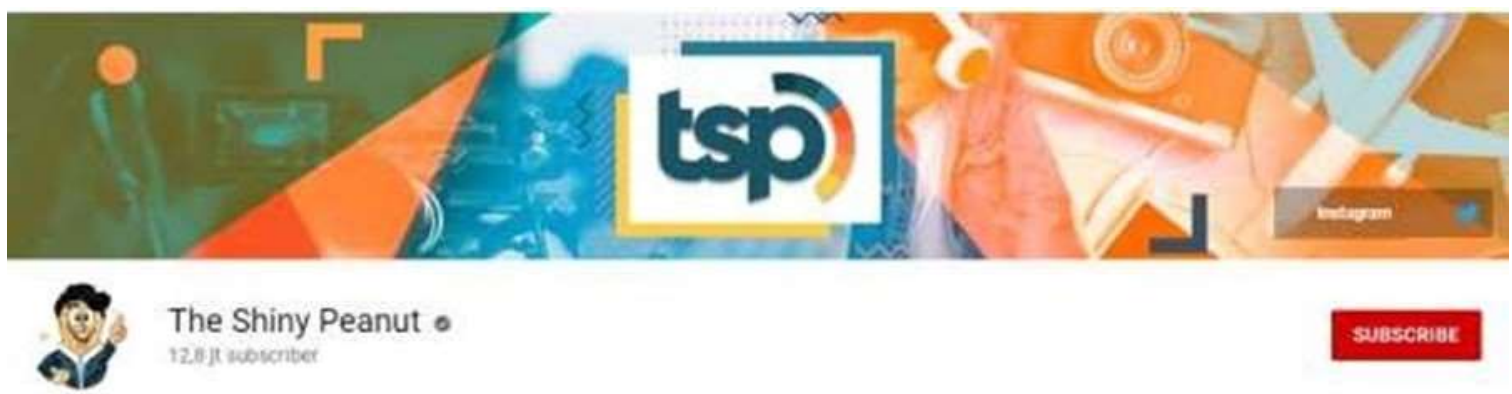

The Shiny Peanut o 120 je wownter

\section{subscruat}

Gambar 9. Akun Youtube the shiny peanuts

Sumber : https://www.youtube.com/results? search_query=the+shiny+pea nuts (akses pada $22-10-2021)$ 


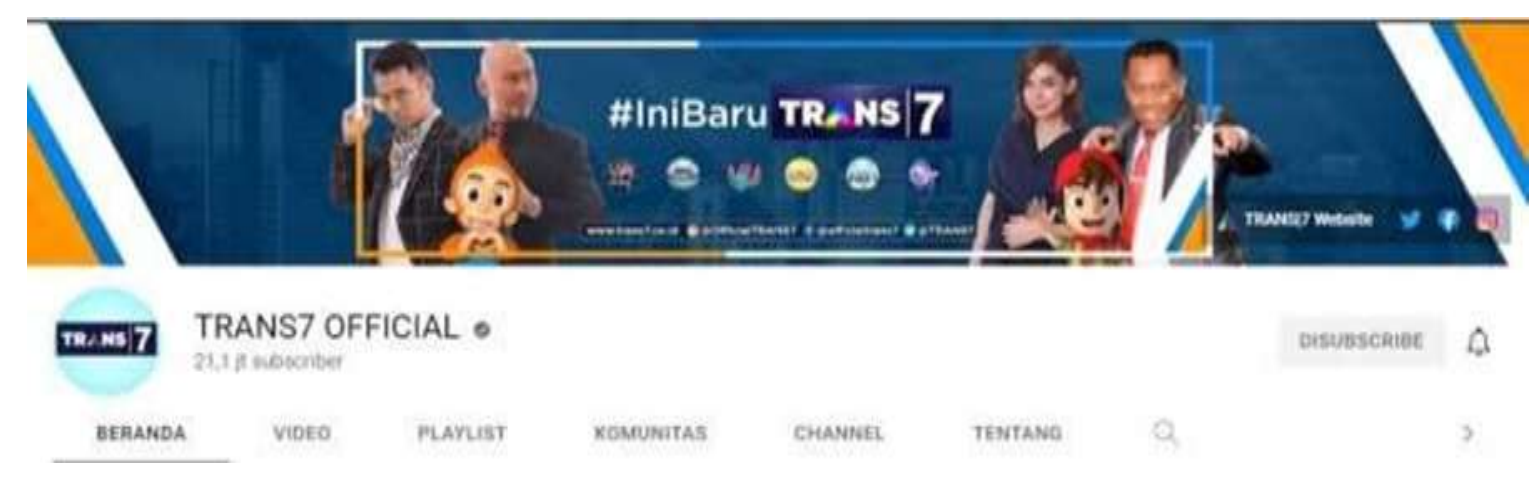

Gambar 10. Akun Youtube trans7 official

Sumber : https://www.youtube.com/results?search_q uery=trans7+official (akses pada 22 10-2021)

Dari ke10 akun youtuber Indonesia Dengan Jumblah Subscribe Terbanyak, peneliti menemukan nilai dari masing-masing variabel yang ada untuk menghitung rasio post to subscribe dari setiap akun. pada akun youtube terdapat yaitu :

- Likes

- Subscribe

- Video share

- video comen

- video like

Dari ketujuh variabel tersebut peneliti hanya fokus untuk menemukan hasil dari 2 variabel, yaitu :

- Video Post

- Subscribe

Dari kedua variabel tersebut kemudian dianalisa sehingga menemukan jumblah nilai dari variabel video post dan variabel subscribe. Untuk menghitung jumblah rata-rata dari variabel video post dan variabel subscribe yaitu dengan cara mengambil semua posting kemudian di hitung sehingga menemukan jumblah niali dari masing-masing variabel. Berikut merupakan tabel jumblah nilai dari masing-masing 10 Youtuber Indonesia Dengan Jumblah Subscribe Terbanyak Yaitu: 
Tabel 1. Analisa Jumblah Nilai Variabel Video post dan Subscribe

\section{Akun Ata Hallilintar}

\begin{tabular}{|l|l|l|}
\hline No & Video Post & Subscribe \\
\hline 1 & 1.226 .000 .000 & 27.900 .000 .000 \\
\hline
\end{tabular}

Tabel 2. Analisa Jumblah Nilai Nilai Variabel Video post dan Subscribe

\section{Akun Ricis official}

\begin{tabular}{|l|l|l|}
\hline No & Video Post & Subscribe \\
\hline 1 & 260 & 27.100 .000 .000 \\
\hline
\end{tabular}

Tabel 3. Analisa Jumblah Nilai Nilai Variabel Video post dan Subscribe

\section{Akun Gen Halilintar}

\begin{tabular}{|l|l|l|}
\hline No & Video Post & Subscribe \\
\hline 1 & 959.00 & 17.700 .000 .000 \\
\hline
\end{tabular}

Tabel 4. Analisa Jumblah Nilai Nilai Variabel Video post dan Subscribe Akun Rans Entertainment

\begin{tabular}{|l|l|l|}
\hline No & Video Post & Subscribe \\
\hline 1 & 10.500 .380 .00 & 21.800 .000 .000 \\
\hline
\end{tabular}

Tabel 5. Analisa Jumblah Nilai Nilai Variabel Video post dan Subscribe Akun Raditya Dika

\begin{tabular}{|l|l|l|}
\hline No & Video Post & Subscribe \\
\hline 1 & 104.000 & 9.520 .000 .000 \\
\hline
\end{tabular}

Tabel 6. Analisa Jumblah Nilai Nilai Variabel Video post dan Subscribe Akun Baim Paula 


\begin{tabular}{|l|l|l|}
\hline No & Video Post & Subscribe \\
\hline 1 & 105.000 & 19.400 .000 .000 \\
\hline
\end{tabular}

Tabel 7. Analisa Jumblah Nilai Nilai Variabel Video post dan Subscribe Akun Jess No Limit

\begin{tabular}{|l|l|l|}
\hline No & Video post & Subscribe \\
\hline 1 & 106.000 & 23.400 .000 .000 \\
\hline
\end{tabular}

Tabel 8. Analisa Jumblah Nilai Nilai Variabel Video post dan Subscribe Akun Deddy Corbuzier

\begin{tabular}{|l|l|l|}
\hline No & Video Post & Subscribe \\
\hline 1 & 938 & 15.900 .000 .000 \\
\hline
\end{tabular}

Tabel 9. Analisa Jumblah Nilai Nilai Variabel Video post dan Subscribe Akun the shiny peanuts

\begin{tabular}{|l|l|l|}
\hline No & Video Post & Subscribe \\
\hline 1 & 200 & 12.800 .000 .000 \\
\hline
\end{tabular}

Tabel 10. Analisa Jumblah Nilai Nilai Variabel Video post dan Subscribe Akun trans7 official

\begin{tabular}{|l|l|l|}
\hline No & Video post & Subscribe \\
\hline 1 & 95 & 14.800 .000 .000 \\
\hline
\end{tabular}




\section{KESIMPULAN}

Tujuan dari penelitian ini adalah mengetahui kredibilitas performa dari akun Youtuber Pada 10 Youtuber Indonesia Dengan Jumblah Subscribe Terbanyak menggunakan Analisis Post To Subscribe. Youtuber Indonesia Dengan Jumblah Subscribe Terbanyak diantaranya: Ata Hallilintar, Jess No Limit, trans7 official, the shiny peanuts, Baim Paula, Raditya Dika Gen Halilintar, Ricis official, Deddy Corbuzier, Rans Entertainment. Dari kesepuluh youtuber tersebut dapat disimpulkan bahwa :

1. peringkat pertama di raih oleh Deddy Corbuzier dengan nilai tertinggi 58,9937107

2. peringkat kedua di raih oleh Jess No Limit dengan nilai tertinggi 45.299.145.299

3. peringkat ketiga diraih oleh Ricis official dengan nilai tertinggi 9.594.095.941

4. peringkat keempat diraih oleh Baim Paula dengan nilai tertinggi 5.412 .371 .134

5. peringkat kelima di raih oleh trans7 official dengan nilai tertinggi 6.41891892

6. peringat keenam di raih oleh Raditya Dika dengan nilai tertinggi 1,09243697

7. peringat ketujuh di raih oleh Rans Entertainment dengan nilai tertinggi 481668807

8. peringat kedelan di raih oleh Gen Halilintar dengan nilai tertinggi $54,180,79$

9. peringkat kesebilan di raih oleh Ata Halilintar dengan nilai tertinggi 0,0439426523

10. peringkat kesepuluh di raih oleh the shiny peanuts dengan nilai tertinggi 156.25 .00 


\section{DAFTAR PUSTAKA}

Holmes, David. "Media Teknologi dan Masyarakat." (2005).

Helianthusonfri, Jefferly. YouTube Marketing. Elex Media Komputindo, 2016.

Wikipedia bahasa Indonesia, ensiklopedia bebas. (2020). YouTube adalah sebuah situs web berbagi video. Www.Wikipedia.Org. https://id.wikipedia.org/wiki/YouTube

Wirga, E. W. (2016). Content Analysis on Youtube Social Media to Support Political Campaign Strategies. Jurnal Ilmiah Informatika Dan Komputer, 21(100), 14-26. https://ejournal.gunadarma.ac.id/index.php/infokom/article/view/1716 